The Canadian Journal of Higher Education

La revue canadienne d'enseignement supérieur

Volume XXXIII, No. 3, 2003 pages 59-86

\title{
Two British Columbia University Colleges and the Process of Economic Globalization
}

\section{JOHN S. LEVIN}

North Carolina State University

\section{ABSTRACT}

This qualitative investigation identifies a condition of frenetic change experienced by organizational members at two university colleges in British Columbia, Canada, during the past decade. Prominent outcomes of the formal designation of five former community colleges as university colleges included curricular change and the evolution of a new institutional mission. The brief history of the university colleges of British Columbia parallels the process of economic globalization in the province of British Columbia, and the responses of managers and faculty at university colleges indicate that globalization influenced the formation and functioning of these institutions.

\section{RÉSUMÉ}

Cette recherche qualitative identifie une condition de changement majeure à laquelle les représentants institutionnels de deux collèges universitaires en Colombie-Britannique, au Canada, ont dû faire face au cours de la dernière décennie. Ainsi, l'identification formelle de cinq anciens collèges communautaires à titre de collèges universitaires a provoqué des changements à leurs programmes d'études et l'évolution vers une nouvelle mission institutionnelle. La brève histoire des collèges universitaires en Colombie-Britannique est semblable au processus de 
mondialisation économique dans cette province, et les choix des personnes en autorité dans les collèges universitaires indiquent que la mondialisation a influencé la formation donnée dans ces institutions ainsi que les modes de fonctionnement de celles-ci.

Established as provincial public colleges in the 1960s, the community colleges of British Columbia were modeled after California's junior colleges yet located in a context that challenged notions of social class imported from the United Kingdom, including views of elitism that placed barriers to higher education and severely limited access beyond the twelfth grade of secondary school. Until the 1960s there was only one higher education institution in the province of British Columbia, and that institution, the University of British Columbia, contributed the educated class to the province's economy and society. Somewhat surprisingly, it was leaders at the University of British Columbia who spearheaded the movement to develop not only additional universities in the province but also regional two-year colleges. Both the University of British Columbia and provincial school trustees exerted considerable influence on the formative years of community colleges in British Columbia (Dennison \& Gallagher, 1986). By the mid-1970s, and specifically through a legislative act in 1977 , the provincial government claimed the role of dominant influencer of British Columbia's colleges (Dennison \& Gallagher, 1986; Levin, 1995). By the 1980s, the colleges were both de jure and de facto a system of provincial colleges, answerable for operations to the government minister. They were both locally responsive and legislatively mandated to meet local needs but they were provincially governed and funded. They maintained a traditional community college orientation and philosophy, including a comprehensive curriculum, open-access to education and training, focus upon student needs, and community responsiveness (Dennison, 1995; Dennison \& Gallagher, 1986; Dennison \& Levin, 1988a; Dennison \& Levin, 1988b; Levin, 1995; Levin, 2001).

Rising pressures upon government for greater access to education and training during the mid-1980s, evident in increasing numbers of students in the province's universities and colleges and documented thousands of 
students unable to obtain places at these institutions, resulted in a government appointed committee to recommend ways to alleviate the stresses upon the postsecondary education system. The findings of the Provincial Access Committee (Province of British Columbia, 1988) indicated that access to university education, specifically to baccalaureate degree programming, was limited and particularly restricted to two geographical areas of the province - the Vancouver region and the Victoria region, areas where the three provincial universities were located in the $1980 \mathrm{~s}$ (Dennison, 1992; Gallagher, 1999; Petch, 1998). The recommendations of the Provincial Access Committee (Province of British Columbia, 1988 ) included the establishment of university colleges that would provide university degree programs through "an upper level university college component" at existing colleges (read community colleges) in densely populated areas outside of Vancouver and Victoria. Government acceded to the access committee's recommendations for establishing university colleges, and three colleges were designated in 1989, with two more designated in the 1990s.

But government's motives and intentions were not solely to provide access to university degree programming. Government economic policy placed university colleges in a contributory role for provincial economic development. Schuetze and Day (2001), in their examination of postsecondary education in B. C. from 1989-1998, while acknowledging that university colleges were part of a government strategy to address the demand for university education, also note that government decisions were "based strongly on brick and mortar investments which were seen as the generating of jobs and enhancing economic development" (pp. 26-27). Other sources indicate that fiscal and economic issues were at the forefront of the reasons for the maintenance of university colleges (Perrin, 2001; University Colleges of British Columbia, 2000). The Assistant Deputy Ministry of Education, Training, and Technology in 1998 (Ciceri, 1998) stated in a letter to the Chair of the University colleges presidents" group that university colleges "play a significant role in preparing students for life and work and in strengthening the economy, both regionally and provincially." The provincial government's strategic plan for colleges (Province of British Columbia, 1996) characterizes the 
degree program component of university colleges as programs "with an applied emphasis and a focus upon employment opportunities." The plan stresses a condition of economic globalization that faces the province and exhorts public postsecondary education institutions to meet the demands of international competition, including keeping pace with technological advances and training a highly skilled workforce (Province of British Columbia, 1996).

\section{Economic globalization}

Globalization and its institutional dynamics are largely understood as an economic theory. Changing modes of production both to capitalize upon labor saving technologies and to exploit a global workforce, for example breaking up production components so that different national locations serve as production sites, are among the defining features of global economic competitiveness. Economic globalization in particular refers to the dominance of the market in organizational and social behaviors and the interventionary role of the state through education, training, and labor market policies (Dudley, 1998). Globalization and responses to globalization, by governments for example, clearly affect practices of institutions (Robertson, 1992). Indeed, institutional agendas reflect the choices available from global forces that promote technological change and market forces, as well as reflect a particular ideology and political decisions at national and regional levels (Held, McGrew, Goldblatt, \& Perraton, 1999). But, globalization is not simply a one-way process. Governments and institutions are both vehicles of globalization and definers of the impact of global forces. This interdependence is a cornerstone of globalization (Robertson, 1992).

Globalization theory has implications for community colleges. Knowles (1995) suggests that in recognizing the presence of a global economy that impinges upon the local environment, community colleges are required to diversify their resource base as well as their program offerings. Organizational actions of community colleges that include alteration to mission and purpose, such as the development and implementation of baccalaureate degree programs, are consistent with the dynamics of economic globalization. Globalization would thus tend to 
affect community colleges by not only stimulating market sensitive behaviors, such as programming for the needs and demands of students and employers, but also their conformation to government policy, such as developing a globally competitive work force by expanding access to higher level educational credentials. Globalization may be viewed through responses of institutional officials - including governing board members, administrators and faculty - and lead to change of organizational paradigm, mission and purpose, culture, or functional processes such as communication mechanisms (Levy \& Merry, 1986): all or any may reflect global flows and responses by such entities as government, the public, or business. These global flows include massive immigration from the East to the West and from the South to the North (Held et al., 1999), technological advances such as electronic network communications (Castells, 1996), changing modes of production (Teeple, 1995), worldwide webs of economic activity (Barnet \& Cavanagh, 1994), and "growing interdependence across the world" (Robertson, 1992, p. 176), particularly economic interdependence.

\section{The study of the university college}

This investigation relies upon qualitative field research methods as well as historical analysis including data collection, data analysis and theory application, modification, and re-application (Berg, 1995; Burgess, 1984; Mason, 1996; Miles \& Huberman, 1994). Postsecondary education in British Columbia constitutes an exceptional case (Yin, 1984). It is this jurisdiction where the first university colleges were established. ${ }^{.}$The research addresses organizational change in the university colleges of British Columbia from their inception in 1989 to the year 2001. Data collection includes interview data from organizational members at two university colleges, document analysis of British Columbia government documents and institutional documents, and observations on site by a research team.

Interview data include interviews with approximately 120 people on site from the period of 1997-2001. Included are data from a sample of administrators and faculty. These organizational members were interviewed during two extended site visits - once in the 1997/98 academic 
year and once in the 1998/99 academic year. Several of these organizational members were interviewed twice. Furthermore, college presidents (there were three at the two colleges during this period) were interviewed during the two site visits and then two were interviewed again in 2000 and 2001. Additionally, in 2001, two college vice presidents, the chair (faculty member) of the Education Council (a senatetype body), a program head, and a faculty union leader were interviewed. Interview questions and responses covered areas that included organizational change as well as curricular and government changes. These questions addressed both determinants and outcomes of the change process.

In addition to interview data, documents were collected over the period of 1989 to 2001 as data sources. Document analysis covered government legislation, government strategic plans and reports, letters between government and institutional officials, government and institutional studies, institutional reports, and formal notes from meetings among college officials. Documents also included institutional budgets, college calendars, and collective agreements, as well as college and student newspapers.

Observational data comprised another data set. Observations were carried out on two separate site visits to two colleges lasting several days each. Research team members from the first site visit and the principal investigator from both site visits noted their observations. The principal researcher maintained a detailed set of notes and written observations during three site visits at the two institutions. These data formed a journal, which included theorizing, such as comparing observations from the sites with established globalization and organization theory.

Data analysis relied upon both globalization theory and organizational change theory (Levin, 2001; Levy \& Merry, 1986; Robertson, 1992) as analytical frameworks. Globalization literature either implicitly or explicitly suggests a number of institutional behaviors influenced by globalizing processes (See Figure 1). These identified behaviors characterize how higher education institutions (their members) respond to global forces as well as to the behaviors of the state in its responses to global forces such as global competitiveness. Behavioral sets or 
Figure 1

\section{Globalization Behaviours}

Category

internationalization

multiculturalism

commodification

homogenization

marketization

workforce training

restructuring

labor alterations

productivity and efficiency

electronic communication and information

state intervention
Abbreviation Code

[I]

[MC]

[COM]

[HOM]

[MRK]

[WT]

[R]

[LA]

[P/E]

[ET]

[SI]

categories include internationalization, multiculturalism, commodification, homogenization, marketization, workforce training, re-structuring, labor alterations, productivity and efficiency, and electronic communication and information. Furthermore, with the role of the state increasing in the affairs and operations of public higher education institutions, the state has become a more noticeable institutional actor, intervening or interfering in colleges' actions. I refer to this set of behaviors as state intervention, although it is not an institutional behavior but rather a behavior of the state acting upon higher education institutions. Some of these sets of behaviors are not present in all organizations, not present simultaneously in an organization, and not enacted in all areas of an organization. These organizational behaviors are not only consistent with globalization but also reflect both the impact of global forces upon higher education institutions and the reproduction of the globalization process (Levin, 2001).

Levy and Merry (1986) develop a conceptual framework for organizational change, premised upon the concept of second-order, fundamental, and enduring change. They employ four main categories of change 
for their framework: paradigmatic change, mission and purpose change, cultural change, and change in functional processes. Paradigmatic change refers to alteration to the assumptions of those who are stakeholders and influencers of the organization. This change also suggests that the organizational world-view has altered: that organizational members define their institution differently and regard their institutional context as altered over time. Mission and purpose refer to intentionality of organizational members and other stakeholders with respect to organizational actions and outcomes. Cultural changes refer to beliefs, norms, and values of organizational members. Functional processes include structures, management, technology, decision-making, and communication patterns. In this investigation, Levy and Merry's (1986) framework is applied to organizational change in university colleges that can be associated or connected with globalizing behaviors.

Two of five university colleges in the province of British Columbia were examined as specific sites. Both institutions are given pseudonyms consistent with researcher and interviewees' understanding of maintaining anonymity. Other indicators of institutional identity, such as specific location, are concealed. Interview, documentary, and observational data from the two institutions - East Shoreline University College and Rural Valley University College - are presented and analyzed.

\section{EAST SHORELINE UNIVERSITY COLLEGE}

Decision-making and deliberation as well as the day-to-day management of East Shoreline University College (ESUC) altered in the past decade, attributable in large part to government action to designate East Shoreline College as a university college and legislation that codified shared institutional governance - a bi-cameral arrangement where a senate-type body of organizational employees and students deliberate over educational and educationally related issues, advising a college board of governors on some matters and conveying their decisions to the board on other matters. "The biggest change for ESUC has been changing to a university model," noted a college administrator. "Most of the college's energy is focused on the degree programs," stated another 
administrator, noting as well that there was a "dramatic evolution from college to university college." Alterations to governance structures and processes at ESUC granted faculty greater decision-making authority and lessened the power of both administrators and the governing board in directing the college.

Furthermore, in addition to legislation on governance, the provincial government and its department responsible for colleges were parties to two other major developments in the latter half of the 1990s: provincialwide collective bargaining and a system-wide strategic plan for the colleges. These two initiatives not only coordinated college actions and decision-making in a number of areas, such as the use of electronic technology in instruction and faculty compensation, but also reduced institutional autonomy. Single institutions depended upon all other similar institutions as a whole as well as upon government. Thus, these actions increased the role of government in the management of each college, including ESUC.

East Shoreline University College expanded considerably in the 1990 s, in student numbers, in programs, and in revenues and expenditures; at the same time, government funding did not keep pace with growth. Thus, in order to support and maintain growth the college enlarged its resource generating behaviors, focusing upon international markets as well as local markets. Although there was less government funding relative to institutional expenditures over a ten-year period, there was increased government influence and control over college behaviors and actions. Government funding behaviors included productivity incentives and targeted funding for specific programs. Government intervention in the collective bargaining relationship between faculty and the college was evident in the establishment of a provincial-wide bargaining structure. Government legislative action changed the composition of all colleges' governing board and established a formal provincial body (Educational Council) to share governance with the institutional governing board and administration. These interventions had considerable influence over college actions and in the development of college structures and processes. Moreover, government permissive legislation 
for baccalaureate degree programs at ESUC affected not only growth but also academic culture and institutional purpose.

These actions, including government policy, government funding behaviors, greater institutional alignment to both international and local markets, and growth itself aided in increasing globalization of ESUC (See Table 1). For example, commodification of higher education can be seen in the exportation and selling of both training and education in Asia, South America, and Europe: this exchange of goods and services for revenues was intended to support institutional growth. Internally, the college emphasized productivity and efficiency, with larger class sizes, fewer administrators, and more reliance upon electronic technology for work: actions intended to cope with budget shortfalls. The college also turned toward workforce training, not so much in providing vocational programs to students, but in providing skills and job-specific training to employers for their workforce and by providing job skills in baccalaureate degree programs. Additionally, privatization grew, with for example the establishment of an international, private secondary school, under the jurisdiction of the college, drawing resources from private citizens in Asia, particularly Japan. In this environment, the college created "winners" and "losers," imitating global economic behaviors. At ESUC, degree programs were viewed as productive and were in high demand; traditional vocational programs - the trades, or vocational programs lost their once prominent position and faltered both in acquiring resources and in demand. College structural change was continual, with re-structuring as a consequence of the establishment of baccalaureate degree programs.

Strategy at East Shoreline University College was a continual response to changing external conditions, including government policy, government funding behaviors, the local demands for education and training, and to a lesser extent to changing global economies (See Table 2). But strategy also included responding to internal demands for change, most particularly and recently for alteration of college purposes and of identity to a university. Fiscal behaviors were predominant, especially in the latter half of the 1990s, as college members deliberated over actions dependent upon funding and resources. The college management 
Table I

Globalization - East Shoreline University College

Themes

Internationalization

\section{Behaviours}

- curricular and program emphasis on international topics

- development and establishment of international secondary school

- foreign sites for faculty development and student work placements

- loss of revenues $(\$ 500,000)$ in $1997 / 98$ as a result of Asian economic downturn

- contract training projects in Asia

Commodification

- college responds to provincial government policy in having education move closer to business

- training and education sold to Asian, South American, and European countries

- college expends energy and resources in marketing both the college and education, locally and internationally

\begin{tabular}{ll}
\hline Homogenization & $\begin{array}{l}\text { measurable outcomes of organizational actions } \\
\text { emphasized }\end{array}$ \\
\hline Marketization & - revenues help to support college growth \\
- president interacts with private sector in search & of revenues for college \\
- competitive environment internally for & resources \\
\hline Workforce training & - shift in emphasis to "life-long learning" \\
& - development of applied degrees \\
- emphasis upon job preparation in Sciences & increasing attention to skills development for \\
& workplace readiness \\
- enrollments in traditional work force training \\
areas diminish
\end{tabular}

(continued...) 
Table I (continued)

Themes

Restructuring

\begin{tabular}{ll} 
& new governance, new funding) \\
\hline Labor alterations & alteration in academic faculty workload \\
& negotiated to permit scholarship and reduce \\
& classroom teaching \\
& new delivery approaches (e.g., on-line \\
& instruction) increase faculty workload \\
& governance structures and processes lessen \\
& managerial control over labor \\
\hline
\end{tabular}

Productivity and efficiency

- increases of class sizes to accommodate growth without increasing costs

- college uses key performance indicators (efficiency measures) for decisions about reductions

\begin{tabular}{ll}
\hline Electronic technology & - administrative systems increasingly automated \\
& experimentation with on-line courses \\
& health sciences and business programs attempt \\
& to respond to increasing use of computers in \\
& clinical settings and in workplace \\
\hline
\end{tabular}

State intervention

- legislated the establishment of university colleges as baccalaureate degree granting

- legislated shared governance

- instituted a three-year tuition freeze

- altered funding policy to more specific targeted funding

- used outcomes measures for decisions and funding allocations 
actively pursued funding sources outside of the traditional government operating grants, and the president of the college devoted considerable time and energy to fund raising and to the acquisition of international contracts in concert with other college officials, including faculty. Strategy was not solely about survival, but was motivated by the desire to grow and to change, that is adapt to external requirements such as changing student and workplace needs.

There were numerous strategies at East Shoreline University College, with some complementary to and others conflicting with organizational behaviors. For example, financial strategies complemented academic growth, but economic concerns superseded educational values. Organizational members expressed both a condition of fatigue over their numerous activities and confusion about institutional direction. The overriding strategy was to take advantage of government legislation that designated East Shoreline College as a university college. "It was unfortunate that participatory governance was introduced at the same time the college was turning to university status," noted a faculty member. "Degree programs are cutting back on introductory courses," noted an adult basic education instructor. "The government transformed the colleges by creating the university college and this led to more work," observed a nursing instructor. While academic faculty, and particularly those in baccalaureate degree programs, worked toward the development of a more prominent academic institution, with increased professional authority and a university culture, vocational and collegiate or nondegree program faculty worked toward program and job survival. Educational services to students at the lower end of the educational hierarchy were jeopardized by the increasing emphasis on higher learning, that is baccalaureate degree programs. Administrative leadership strategies involved actions directed to growth, productivity, and labor-management stability. These strategies translated into administrative work in securing resources, in managing budgets with both art as well as craft, and in intense political lobbying, internally with organizational members and externally with government officials.

The comprehensive nature of the college curriculum, from college preparation to trades training to baccalaureate degrees, resulted in a 
Table 2

\section{Strategy — East Shoreline University College}

\section{Description}

Enlarge academic program area by developing and establishing baccalaureate degree programs.

Cope with growth and government funding inadequacies by increasing contract training and international student revenues.

Promote college services and programs locally and internationally.

\section{Emphasize committee structure} for decision-making.

\section{Intended Outcomes}

Accomodate more students; satisfy internal and external demands for degree programs; achieve university status.

Generate revenues to support growth in education and training areas of college.
Respond to local demand; attract international students for revenue.

Model university behaviours to achieve university status; shift balance of internal influence away from administrators and toward faculty; cope with new issues arising from the establishment of baccalaureate programs (e.g., research ethics, greater expertise for decision-making).

Emphasize role of president as fund raiser and college program and service promoter.

Accomodate growth through major building projects.

Increase electronic technology use and purchase of equipment for both administrative work and instruction.

\section{Emphasize international activities and services.}

Change structures, including department and unit alignments.
Raise money; improve profile of the institution locally and internationally.

Provide space especially for new degree programs and for vocational programs.

Increase productivity; experiment with alternate delivery systems (e.g., distance education); serve more students; upgrade faculty skills; improve administrative operations.

Gain revenues; develop opportunities for faculty and students for professional and educational growth.

Adapt to fiscal conditions; seek opportunities to expand, to acquire resources, to achieve greater efficiencies; respond to changing personnel needs; adapt to administrative personnel retirements and resignations. 
student body that was diverse in both interests and abilities. Thus, institutional strategies directed toward student interests and needs were diffuse. Strategies for students occurred at the unit or program level, not at the institutional level. For example, the Forestry Technology program altered curriculum and instruction to adapt to a changing workplace and to increase student opportunity for employability. The Nursing program dramatically changed its curriculum so that graduates could adapt to the changing health care environment of the province. These unit or program strategies were not always compatible or consistent with larger institutional strategies, but because the college operated as a collection of relatively autonomous work areas, the inconsistencies were not regarded as problems.

The overall institutional strategy of responsiveness to environmental opportunities, such as new institutional status as a university college, was consistent with organizational functions of growth and survival (Mintzberg, 1983). Nonetheless, in choosing these strategies, East Shoreline University College experienced several critical internal conflicts, such as the "schism between university and vocational programs" (Adult basic education faculty) and emphasis on "training for slots rather than education" (Science faculty), all suggestive of "a major cultural change" (Administrator).

\section{RURAL VALLEY UNIVERSITY COLLEGE}

Rural Valley University College (RVUC) experienced considerable growth in the last decade, nearly doubling its full-time equivalency (FTE) student numbers to approximately 3800 FTE by $1996 / 97$. Institutional growth was precipitated by two major factors: local population growth and the establishment of a limited number of baccalaureate degree programs at the institution. These factors resulted in significant alterations in various areas, such as resources and facilities, personnel, curriculum, and governance. The college's budget, for example, expanded $200 \%$ over the period of $1990 / 91$ to $1995 / 96$, a $40 \%$ per year growth. In the 1990s, the college hired approximately 100 full-time faculty. In addition, major facility expansion and dramatic curricular 
change, the development and offering of four-year degree programs in the Arts and Social Sciences, in career-oriented areas such as Nursing, and in selected Science areas, altered both institutional mission and internal relationships. For one faculty member, the increase in size meant that long-time colleagues were no longer "physically crossing paths;" for other faculty, the historically close connection to the local community gave way to preoccupation with internal processes such as governance, co-ordination of work, labor relations, and, not least of all, academic professionalism which included program and professional development. Finally, the development of baccalaureate programs led to reform in institutional governance.

While maintaining many of their former processes and behaviors of decision-making, college personnel continued to adjust to the new governance structures and processes. One identified change was that the individual units, or disciplines, were more independent than in the past, likely the consequence of new faculty with doctoral degrees and experience largely in university environments. The institution was "moving out of an older model," according to an English instructor, whether that model was conceived of as a labor-management model, a collegial model of a small institution, or a traditional community college model that values a "practitioner's culture" (McGrath \& Spear, 1991) rather than professional expertise and focuses upon student personal and social development instead of cognitive and intellectual development.

Organizational culture altered to accommodate two distinct institutions, a community college and a university. Described characterizations of Rural Valley University College suggested that there were at least two institutions - a community college and a university. "RVUC is both a university and a community college," asserted a college dean. "The mission has changed its focus to upper-level," observed a vocational instructor. This alteration was both foundational as well as stressful. "We have a new identity," asserted a union official. The college's president stated, "we are moving toward a university model." "There is a problem of equilibrium between the community college and the university college," noted a social science department head. "We question whether we have 
gone in too many directions," observed a humanities faculty member and union official.

Four dominant behaviors signal the impact of global forces upon Rural Valley University College (RVUC). These included education and training, governance, financing, and labor-relations (See Table 3). All of these behaviors emanate from the provincial government and its departments or agencies. To improve the economy, buffeted by international markets and economies, government policy supported and indeed promoted workforce training, higher-level educational attainment, and higher-level participation rates, not least to reduce the high provincial unemployment figures. The province "faces a change in interfacing with the world," noted the president of RVUC. Government expended millions of additional dollars in the early 1990s to support the evolution of university colleges. Outcomes of the development of university colleges in the province, and this was the case for RVUC, included massive growth in student numbers, faculty, and facilities. An unintended outcome was major growth in fields not traditionally connected to employment or job training - the liberal arts. Accompanying this growth was increasing academic professionalism and provincially coordinated faculty union power. In the mid-1990s, the government enacted legislation to alter governance structures at colleges so that faculty had not only voice in decision-making but also a partially shared role with administrators in managing the institution, as faculty were given plurality representation on an educational council, the preeminent academic decision-making body in the institution. Government intervention altered not only organizational functioning but also organizational culture as the institution rapidly adopted behaviors characteristic of a university.

At Rural Valley University College, alterations from a two-year to a four-year institution led to reduced attention to the local community and greater attention, initially, to internal academic concerns and governance and management matters, such as scholarship, program credibility, and university status. It has also led to tensions among groups, as some areas prospered and others became impoverished and disillusioned, reproducing in microcosm the concept of "winners and losers" characteristic of economic globalization. Thus internal allocation of resources was a 
Table 3

\section{Globalization - Rural Valley University College}

Themes

Internationalization

\section{Behaviours}

- increasing international student numbers over the decade until 1997/98

- 175 students in 1996/97 generated \$2 million revenue, up by $\$ 500,000$ over $1995 / 96$

- loss of students in 1997/98, over 10\% during Asian economic turndown

- 1995/96, associate degree program in international studies, for students looking for careers in business, journalism, government

Commodification

- consumer demand for choice and service: "students demand flexibility and access"

- college becoming more entrepreneurial and fiscally aggressive, more like a business

Homogenization

- enrollment growth rewarded with government funding; decline or stagnation is punished

- centralized bargaining standardizes relationships at the local level, reducing autonomy in labor relations

\begin{tabular}{ll}
\hline Marketization & use of international education as revenue \\
& generator \\
- use of continuing education as revenue & generator \\
- & serve local business and industry through \\
& contract training in order to generate revenues \\
\hline Workforce training & new institutionally-based training program \\
captures former welfare-to-work clientele \\
- emphasis on new skills in health sciences, with \\
changing role of nursing, from hospital to \\
community \\
- programs seek competitive edge through \\
applied experiences in Liberal Arts
\end{tabular}

(continued...) 
Table 3 (continued)

Themes

Restructuring

\section{Behaviours}

- loss of jobs of seven full-time and part-time faculty as a result of downsizing

- elimination of position of Dean of Education Support and integration of units within that area with other areas

- growth in Liberal Arts area led to separation of Social Sciences and Humanities - now more "autonomous"

Labor alterations

- faculty duties include more counseling and assessment of students

- no layoff clause negotiated to protect faculty job security concerns (1994-97 contract)

- role and responsibilities of departmental chairs in spotlight because of devolution of work from senior administrators

- loss of faculty in program areas because of low enrolments

Productivity and efficiency

- government strategic plan "wants faculty to work harder" and "produce more students"

- non-credit courses that are not cost-recovery are "axed"

- government restricts funding and pressures college to seek partnerships with private sector and to increases efficiencies

- college drops programs (e.g., office careers) and merges departments

- pressure on faculty "to have maximum numbers of students"

- internal debates about the use of technology, especially computer instruction

- 1994-97 collective agreement item on new modes or models of instruction and technological change; interactive distance education classes with other colleges

- 1,000 new computers on campus

(continued) 
Table 3 (continued)

Themes

\section{Behaviours}

- new management system implementation of software system (Banner) for financial, student and human resources management

- computers and electronic technology in instruction, e.g., physics

State intervention

- legislation in mid-1990s to alter mission and purpose of college

- government agreement with provincial faculty association to embark upon system-wide collective bargaining

- development and implementation of provincial strategic plan

- governnment introduction of performance indicators

- government introduction of new funding policy targeted and competitive funding

factor of institutional change, creating both "haves and have-nots." And, following the early 1990s efforts to establish university colleges, government funding altered both in its largesse and in its laissez-faire approach to oversight.

Beginning in the mid-1990s, government-funding behaviors were more restrictive and controlling. However, there was less public sector funding from the provincial government relative to institutional growth. As a share of revenue, provincial grants fell from $72 \%$ of total revenues to $69 \%$, whereas tuition fees rose from $15 \%$ to $21 \%$ of total revenues. This shift suggests that public sector spending reductions meant increased private consumer spending, a clear example of the privatization of public education. Furthermore, and probably most significant, government began to fund by applying competitive measures whether outcomes measures of institutional productivity or input measures for lowest cost - in order to control college institutional behaviors and actions. Thus, Rural Valley University College as an evolving, 
developing, and growing institution in the early 1990s was required to accept and abide by government policy if maintenance of growth was to be preserved in the latter part of the 1990s. Government policy included furthering privatization of college services and increasing productivity.

Institutional responses to government actions were also influential in organizational change. On the one hand, Rural Valley University College exhibited increasing characteristics of a business: homogenizing and commodifying its educational and training products so that these would appeal to business and government agencies. Thus market behaviors were ascendant. On the other hand, university college status and baccalaureate programming for the college led to growth, expansion of mission, and the elaboration of structure, as the institution became a larger and more complex place.

There is growing centralization; structural change is underway. (College president)

Deans are now seen as managers and faculty are seen as experts. (Economics faculty member)

As a result of new university college status, departments are more independent... There is more administration at the department level and [the] role of department heads has expanded. (Union official)

There is a trend toward inter-disciplinarity. (Social Science department head)

For some, the new mission and function resulted in a substantially altered relationship between the college and its community.

There are divisions within the college, tensions between the university college and local needs. (Health sciences department head)

In resolving the tensions among its community orientation, its local focus, and its more cosmopolitan and professional orientation, Rural Valley University College moved toward a university model, in spite of dissension from numerous organizational members who were devoted to serving their local communities and all educational and social levels of those communities. 
We have shifted from a community college to [a] degree granting [institution]: this still affects the old guard who has old expectations. (English department head)

Strategy at Rural Valley University College contained contradictory ideas: develop into a four-year degree granting institution while maintaining the purposes of a community college. Furthermore, there was considerable intent and effort to acquire resources for sustaining growth and development (See Table 4). The effects of implementation of these strategies produced impediments. The tensions inherent in developing four-year degree granting institutions and simultaneously maintaining a community college have been discussed above. The strategy to secure additional resources is discussed below.

The pursuit and acquisition of resources by college members were responses both to perceived government deterioration in funding and to government policy and funding incentives for institutions so they would rely less upon government and more upon the private sector. One notable contradiction here was that government "froze" tuition fees for a threeyear period, nullifying the student as a source of non-government funding. Rural Valley University College expanded its contract services activities, its international education behaviors which until 1997 led to increasing student numbers, and its partnerships with school districts and civic government in order to acquire more resources. But, these actions served largely to off-set not supplement provincial government funding grants, and by 1996/97, the college found itself with less revenue than in $1995 / 96$, although it had about $\$ 4$ million more than in 1993/94. Because government moved base grant funding money to competitive one time funding, the college could not rely upon either competitive funding for more than a year or upon "earned revenues" from contracts as on-going sources of funds. Thus, the acquisition of non-base funding was not compatible with the functioning of an educational enterprise, especially one that offered four-year degree programs, because the educational behaviors required a stable context over an extended time period, and the sources to support those endeavors were transitory and unstable. 
Table 4

\section{Strategy - Rural Valley University College}

Description

Develop and offer four-year degree programs in the Arts and Sciences and occupational fields.

Maintain comprehensiveness in curriculum that maintains the mission of the community college.

\section{Intended Outcomes}

Serve more students, grow, provide alternatives to university education in the local community.

\begin{abstract}
Maintain community college identity while developing into a four-year degree granting institution; continue to serve all segments of the community.
\end{abstract}

Become more "entrepreneurial," more aggressive externally with the generation of funds.

Improve and document institutional outcomes, including services, employee socialization, employee participation in decision-making.
Finance growth; decrease dependancy upon government funding.

Increase productivity; help employees adjust to change; improve institutional climate and maintain healthy labor relations.

\section{Agents of globalization}

The evolution of baccalaureate programs in university colleges blossomed most in the Liberal Arts, yet the government's priorities were jobs and workforce training, with education as a means to decrease unemployment and improve the economy to stimulate government revenues. The demand for and growth of liberal arts-oriented programming outstripped expectations. Although professional, work-related programs such as Nursing and Education were in demand, the Bachelor of Arts degree was the most numerous credential attained. Of 1,283 baccalaureate degrees granted in 1999 at the five university colleges in British Columbia, 402 or $31 \%$ were Bachelor of Arts degrees (University Colleges of British Columbia, 2000).

While government policy in the late 1980s and early 1990 s, under two separate governing parties, was favorable to baccalaureate programming 
at community colleges, government policy in the mid and late 1990s emphasized institutional productivity and workplace skills in education, as well as closer institutional-private sector relationships and ventures. In responding to a faltering economy, the provincial government applied neo-liberal approaches to funding the public sector. Some college programs as a result faced elimination or reduction; there was a provincial moratorium on facility construction; and base funding was reduced with additional funds available on a competitive basis, with criteria set by government. As noted previously, in order that colleges did not seek additional revenues from students to fund expansion, the government placed a "freeze" on tuition fees. Finally, labor relations moved in the 1990s from the local level to the provincial level, requiring a system-wide approach to both personnel relations and to labor. This pattern suggests as well that an industrial model of state control over production in education and training evolved in the province so that the government had more control over the economy.

The provincial government served as an intermediary force, buffering the college from direct confrontation with global forces of change and translating those forces to its own political agenda. This political agenda contained several social goals, such as increasing access to postsecondary education and training, and several economic goals, such as reducing the burden on government for postsecondary system expansion. These goals were not necessarily compatible, or at least they provided tensions and conflicts to those institutions that were coping with these goals. Conditions at both Rural Valley University College and East Shoreline University College demonstrate some of the tensions operating in institutions with the presence of globalizing behaviors, such as greater government involvement in college operations coupled with government policies that promote reduced institutional dependence upon government for fiscal resources.

Government was not the sole agent of globalization in the colleges of British Columbia. Administrators and faculty furthered the globalizing process by their actions to establish and develop their institutions as university colleges, including the provision of baccalaureate degrees, the elaboration of structures, and the advancing of professionalism. Students, 
too, served as agents of change by enrolling in increasing numbers in these institutions and particularly by their program choices: programs that were credentialed at the baccalaureate level. The communities, too, primarily in the form of organized bodies such as the Chamber of Commerce, local hospitals, and school districts, promoted the new status of university colleges and supported college efforts to implement new baccalaureate degree programs. These efforts shifted the focus of community colleges, now university colleges, to the economic marketplace and toward the preparation of a globally competitive workforce.

Neither the relative autonomy of the state (Dougherty, 1994) nor the independence of institutional officials (Brint \& Karabel, 1989) is a sufficient explanation for organizational change and the transformation of community colleges to university colleges. Government officials and politicians responded to economic globalization as well as to public pressure for advanced degree opportunities. Governing boards, administrators, and faculty responded to government policy and incentives as well as to their own aspirations and their communities' perceived needs. The baccalaureate degree serves several functions: it is an internationally recognized credential, raising the profile and the prestige of public colleges in British Columbia; it signifies advanced education at a level appropriate for a knowledge-based economy (Reich, 1991); and it serves as an efficient way for providing increased access to postsecondary education. Combining both traditional liberal arts curricula (such as English literature, Psychology, and Biology) and professional programs (such as Nursing and Education), university colleges also maintain a comprehensive community college curriculum: they have expanded their mission and their growth in students, in employees, and in resources has continued unabated since their inception.

In spite of the growth of university colleges, the development of a hybrid institution, merging a functioning community college with the concept of a university or four-year college, suggests clashes with differing expectations and value systems. For example, while the community college promotes egalitarianism, the university champions expertise; and while the community college's mission is expansive and multi-faceted, the university's traditional mission is three fold: teaching, research, and 
service. The dual mission that has emerged within university colleges is indeed the nexus of competing value systems and these have their correspondence in the globalization debate. Whether the issue is the preservation of a way of life, for example forestry and fisheries, or the preservation of species and vegetation, economic globalization both quickens the pace of change and heightens resistance to change. Community colleges continue to be viewed by governments, organizational members, and the public as serving the needs of the state and their communities, thus the pressure to provide education and training to develop a competitive workforce and to enhance students' marketability will mount. Baccalaureate degree granting status for community colleges was a momentous turning point in the evolution of an institution.

\section{Notes}

1 Another point of view is that the province of Nova Scotia is the origin of the university college. The University College of Cape Breton possesses many of the characteristics of "community colleges," and evolved into a baccalaureate degree institution. The institution was at its inception a "satellite" or branch campus of St. Francis Xavier University. In 1974, the "satellite" campus was united with Eastern Tech and became the College of Cape Breton. In 1982, the government of Nova Scotia legislated baccalaureate degree-granting status to the College of Cape Breton, and the institution became the University College of Cape Breton (University College of Cape Breton, 2001).

\section{References}

Barnet, R., \& Cavanagh, J. (1994). Global dreams: Imperial corporations and the new world order. New York, NY: Simon \& Schuster.

Berg, B. (1995). Qualitative research methods for the social sciences. Boston, MA: Allyn and Bacon.

Brint, S., \& Karabel, J. (1989). The diverted dream: Community colleges and the promise of educational opportunity in America, 1900-1985. New York, NY: Oxford University Press. 
Burgess, R. (1984). In the field: An introduction to field research. London, UK: George Allen and Unwin.

Castells, M. (1996), The rise of the network society. Cambridge, MA: Blackwell

Ciceri, R. (1998). Letter to Richard Johnston, President, East Shoreline University College, February 3.

Dennison, J.D. (1992). The university-college idea: A critical analysis. The Canadian Journal of Higher Education, 22(1), 109-124.

Dennison, J. D.(1995). Challenge and opportunity. Vancouver, BC: The University of British Columbia Press.

Dennison, J.D., \& Gallagher, P. (1986). Canada's community colleges. Vancouver, BC: The University of British Columbia Press.

Dennison, J.D., \& Levin, J.S. (1988a). Canada's community colleges in the nineteen eighties: Renewal and responsiveness. Toronto, $\mathrm{ON}$ : Association of Canadian Community Colleges.

Dennison, J.D. \& Levin, J.S. (1988b). Goals of community colleges in Canada: A 1987 perspective. The Canadian Journal of Higher Education, $28(1), 49-63$.

Dougherty, K. (1994). The contradictory college. Albany, NY: State University of New York.

Dudley, J. (1998). Globalization and education policy in Australia. In J. Currie \& J. Newson (Eds.), Universities and globalization, (pp. 21-43). Thousand Oaks, CA: Sage Publications.

Gallagher, R. (1999). A vanishing vision - part II? A discussion paper (draft). January.

Held, D., McGrew, A., Goldblatt, D., \& Perraton, J. (1999). Global transformations: Politics, economics and culture. Stanford, CA: Stanford University Press.

Knowles, J. (1995). A matter of survival: Emerging entrepreneurship in community colleges in Canada. In J. Dennison (Ed.), Challenge and opportunity. (pp. 184-207). Vancouver, BC: The University of British Columbia Press.

Levin, J. (1995). Power in the British Columbia community college. B.C. Studies, 107. Autumn, 60-80.

Levin, J. (2001). Globalizing the community college: Strategies for change in the twenty-first century. New York. NY: Palgrave/St. Martin's Press.

Levy, A., \& Merry, U. (1986). Organizational transformation: Approaches, strategies, theories. New York, NY: Praeger.

McGrath, D., \& Spear, M. (1991). The academic crisis of the community college. Albany, NY: State University of New York Press. 
Mason, J. (1996). Qualitative researching. Thousand Oaks, CA: Sage Publications.

Miles, M., \& Huberman, A. (1994). Qualitative data analysis. Thousand Oaks, CA: Sage Publications.

Mintzberg, H. (1983). Power in and around organizations. Englewood Cliffs; NJ: Prentice Hall.

Perrin D. (2001). Toward regional comprehensive universities: Legislation for BC's university colleges. Draft \#2, The University Colleges of British Columbia, April 27.

Petch, H. (1998). Degree programs at the university colleges: A British Columbia success story. A report prepared by Howard Petch at the request of the presidents of the university colleges of British Columbia. Victoria, BC, July.

Province of British Columbia, Ministry of Education, Skills and Training. (1996). Charting a new course: A strategic plan for the future of British Columbia's colleges. Victoria, BC

Province of British Columbia, Ministry of Advanced Education. (1988). Access to advance education and job training in British Columbia. Report of the provincial access committee. Victoria, BC

University colleges of British Columbia. (2000). 1999-2000 Annual Report.

Report of the Provincial Access Committee. (1988). Access to Advanced Education and Job Training in British Columbia. Victoria, BC

Reich, R. (1992). The work of nations. New York, NY: Vintage Books.

Robertson, R. (1992). Globalization: Social theory and global culture. London, UK: Sage Publications.

Schugurensky, D., \& Higgins, K. (1996). From aid to trade: New trends in international education in Canada. In R. Raby \& N. Tarrow (Eds.), Dimensions of the community college: International, intercultural and multicultural, (pp. 53-78). New York, NY: Garland Publishing.

Schuetze, H., \& Day, W. (2001). Postsecondary education in BC 1989-1998: The impact of policy and finance on access, participation, and outcomes. Center for Policy Studies in Higher Education and Training. University of British Columbia, March.

Teeple, G. (1995). Globalization and the decline of social reform. New Jersey: Humanities Press.

University College of Cape Breton. (2001). Web site, November.

Yin, R. (1984). Case study research. Newbury Park, CA: Sage Publications. 